\title{
Evidence of Sulfur-bound Reduced Copper in Bamboo Exposed to High Silicon and Copper Concentrations
}

\author{
Blanche Collin ${ }^{\mathrm{a}, \mathrm{b}}$, Emmanuel Doelsch ${ }^{\mathrm{c}}$, Catherine Keller ${ }^{\mathrm{a}}$, Patrick \\ Cazevieille ${ }^{c}$, Marie Tella ${ }^{c}$, Perrine Chaurand ${ }^{a}$, Frédéric Panfilib, Jean- \\ Louis Hazemann ${ }^{d}$, Jean-Dominique Meunier ${ }^{\mathrm{a}}$ \\ a CEREGE, CNRS, Aix-Marseille Univ., Europôle méditerranéen de l'Arbois BP 80, 13545 Aix en \\ Provence, France \\ b Département de recherche développement de la société PHYTOREM S.A., chemin de l'Autodrome, \\ 13140 Miramas, France \\ c CIRAD, UPR Recyclage et risque, Avenue Agropolis, F-34398 Montpellier, France \\ d Institut Néel, CNRS and Université Joseph Fourier, BP 166, F-38042 Grenoble Cedex 9, France
}

\begin{abstract}
Due to its high growth rate and biomass production, bamboo has recently proven to be useful in wastewater treatment. Bamboo accumulates high silicon (Si) levels in its tissues, which may improve its development and tolerance to abiotic stresses, such as metal toxicity. We examined copper $(\mathrm{Cu})$ absorption, distribution and toxicity and the role of a silicon (Si) supplementation in the bamboo. Bamboos Phyllostachys fastuosa were maintained in hydroponics for 4 months and submitted to two different $\mathrm{Cu}\left(1.5\right.$ and $\left.100 \mu \mathrm{m} \mathrm{Cu}{ }^{2+}\right)$ and $\mathrm{Si}(0$ and $1.1 \mathrm{mM}$ ) concentrations. $\mathrm{Cu}$ and Si partitioning and $\mathrm{Cu}$ speciation were investigated by chemical analysis, microscopic techniques (cryo-scanning electron microscopy, laboratory based micro X-ray fluorescence spectroscopy) and spectroscopic techniques (X-ray absorption near-edge structure and extended X-ray absorption fine structure).

Inhibitory effects of $\mathrm{Cu}$ on plant growth were observed at the highest $\mathrm{Cu}$ concentration. $\mathrm{Si}$ supplementation reduced the visible toxicity symptoms (chlorosis and brown coloration of roots) but did not significantly modify the $\mathrm{Cu}$ concentration. Cu concentration varied over a root>stem $\geq$ leaf gradient. Microscopic analysis of root cross-sections revealed that $\mathrm{Cu}$ was mostly detected in epidermal cells region, whereas Si had mainly accumulated in the endodermal cell region. $\mathrm{Cu}$ was present in two oxidation states: $\mathrm{Cu}(\mathrm{I})$ and $\mathrm{Cu}(\mathrm{II})$ with different ratios in different plant parts. The main strategies of bamboo to cope with high $\mathrm{Cu}$ concentrations in its tissues include: (i) high sequestration in the root, (ii) $\mathrm{Cu}$ (II) binding to amino and carboxyl ligands (iii) the formation of $\mathrm{Cu}(\mathrm{I}) \mathrm{S}$ organic compounds, and (iv) the formation of an inorganic $\mathrm{Cu}(\mathrm{I}) \mathrm{S}$ compound that may be involved in $\mathrm{Cu}$ storage. Although $\mathrm{Si}$ did not significantly improve bamboo $\mathrm{Cu}$ tolerance, $\mathrm{Si}$ supplementation modified $\mathrm{Cu}$ speciation in above-ground parts by increasing the proportion of organic and inorganic $\mathrm{Cu}(\mathrm{I}) \mathrm{S}$ compounds.
\end{abstract}

